\title{
Petisi Indonesia untuk Dunia: Potret Globalisasi Gerakan Sosial Digital
}

\author{
Andreas Ryan Sanjaya \\ Program Studi Ilmu Komunikasi, Universitas Katolik Soegijapranata \\ mail.ryansanjaya@gmail.com
}

\begin{abstract}
Internet technology brought out about changes in human life. The apparent changes in this study lied in two respects. First, changes in the way citizens conduct social movements. Second, the internet reinforces the impact of globalization, so the issues raised by citizens are also a global issue. This study revealed a portrait of globalization in the digital social movement in Indonesia. The selected case is an online petition addressed to international parties for genocide in Myanmar. The analytical approach in this study used social semiotics. The three components analyzed were field of discourse, tenor of discourse, and mode of discourse. The result was a petitioner used international criminal issues, as well as provocative terms to reinforce the message in the text.
\end{abstract}

Keywords: globalization, online petition, social movement, social semiotic

\begin{abstract}
Abstrak
Teknologi Internet membawa perubahan pada kehidupan manusia. Perubahan yang tampak dalam penelitian ini terletak pada dua hal. Pertama, perubahan pada cara warga melakukan pergerakan sosial. Kedua, internet menguatkan pengaruh globalisasi, maka isu-isu yang diangkat oleh warga juga merupakan isu global. Penelitian ini mengungkap potret globalisasi dalam gerakan sosial digital di Indonesia. Kasus yang dipilih adalah petisi online yang ditujukan kepada pihak internasional atas kasus genosida di Myanmar. Pendekatan analisis dalam penelitian ini menggunakan semiotika sosial. Tiga komponen yang dianalisis adalah medan wacana, pelibat wacana, dan sarana wacana. Hasilnya adalah pembuat petisi menggunakan isu-isu kejahatan internasional, serta istilah-istilah provokatif untuk menguatkan pesan dalam teks.
\end{abstract}

Kata Kunci: gerakan sosial, globalisasi, petisi online, semiotika sosial

\section{Pendahuluan}

Sejak kekuasaan Orde Baru di Indonesia melemah, berbagai gerakan sosial mulai bermunculan dan makin berani unjuk diri. Gelombang protes besar-besaran dari rakyat dan mahasiswa pada 1998 menjadi penanda akan hadirnya era baru dalam politik di Indonesia, yakni era reformasi. Wacana yang diperjuangkan pada era reformasi tersebut adalah mengembalikan mandat dan kekuasaan kepada rakyat. Pada era sebelumnya, Presiden Soeharto telah menunjukkan praktikpraktik pemerintahan tirani dengan membungkan segala bentuk protes yang bisa dilakukan baik oleh media massa maupun rakyat secara umum. 
Ketika teknologi internet mulai menjadi kebutuhan penting bagi kehidupan warga terutama di perkotaan, muncul pola-pola komunikasi yang berubah dalam gerakan sosial. Sebelum internet muncul, warga berkonsolidasi dalam gerakan sosial secara langsung dan tatap muka. Konsekuensi dari model ini adalah keterbatasan penyebaran isu, keterbatasan massa, serta kebutuhan akan ruang dan waktu yang tidak sedikit. Teknologi Internet yang didukung dengan kemudahan akses melalui berbagai jenis gadget mengatasi persoalan-persoalan tersebut.

Dalam konteks aktivitas gerakan sosial, perubahan teknologi ini turut mengubah bagaimana warga dan para aktivis berkomunikasi, berkolaborasi, dan berdemonstrasi (Garrett, 2006). Meski demikian, tujuan dari tindakan berkomunikasi secara elektronik ini bukanlah untuk menggantikan komunikasi personal (Schesser, 2006). Hal yang ingin dicapai adalah kesadaran warga untuk berpartisipasi secara politik.

Partisipasi secara politik ini secara konvensional tampak dalam gerakan sosial yang melibatkan banyak orang. Teknologi internet mengubah struktur pergerakan sosial (Donk, Loader, Nixon, \& Rucht, 2004). Ketika metode berkomunikasi yang konvensional cenderung mahal dan terpusat, teknologi membuatnya tidak lagi demikian. Teknologi memang bisa memperkuat pengelolaan komunikasi yang efektif dan terpusat, tetapi bukti empiris juga menunjukkan bahwa teknologi dapat pula digunakan untuk menghubungkan pendapat-pendapat lain dan juga menggerakkan aktivis atau komunitas secara fisik.

Perubahan terjadi pula pada bagaimana warga menyampaikan petisi. Petisi adalah salah satu bentuk tindakan warga untuk melakukan tekanan kepada pemerintah terkait dengan gerakan sosial yang mereka perjuangkan. Jika sebelumnya tanda tangan dikumpulkan secara manual, kini dalam waktu singkat sebuah petisi bisa ditandatangani oleh puluhan ribu orang. Informasi tentang petisi tersebut bisa disebar melalui surat elektronik maupun jejaring-jejaring sosial.

Petisi online (selanjutnya disebut dengan "petisi daring") ini dibuat dengan menggunakan sebuah platform yang mudah diakses oleh warga. Hanya dengan duduk dan mengakses internet, warga bisa turut berpartisipasi menandatangani petisi mengenai suatu isu yang diperjuangkan. Salah satu situs yang menyediakan fasilitas tersebut adalah Change.org. Situs Change.org ini berasal dari Amerika Serikat tahun 2007 dan baru memperluas bisnisnya di Indonesia tahun 2012 lalu. Gerakan sosial secara global telah membuat situs ini dirasa perlu untuk didirikan di Indonesia. Kaitan antara globalisasi dengan media dengan demikian bukan hanya terjadi pada media massa melalui isu dan model bisnis yang mereka jalankan. Model partisipasi warga yang berbasiskan Internet juga menjadi kegiatan yang terkena arus globalisasi.

Hal yang akan ditekankan pada tulisan ini adalah tanpa benar-benar disadari oleh publik, situs Change.org yang sering digunakan ini adalah salah satu bentuk globalisasi. Seperti halnya pada bidang lain, globalisasi dalam hal ini juga dilakukan oleh negara maju, yang kemudian diadopsi oleh negara berkembang. Disana ada upaya untuk membuat publik yang mengakses situs tersebut menjadi sama rasa, sama-sama berjuang, berada dalam identitas yang seragam, dan 
disatukan oleh platform yang dapat membuat keinginan mereka didengarkan oleh otoritas terkait.

Berangkat dari gagasan tersebut, maka penelitian ini mengajukan rumusan masalah: Bagaimana petisi daring menunjukkan potret globalisasi gerakan sosial digital di Indonesia? Penelitian mengenai hal ini penting untuk dilakukan mengingat globalisasi yang terjadi yang diakibatkan oleh perkembangan pesat teknologi internet ini adalah fenomena baru yang menunjukkan solidaritas warga secara global. Maka penelitian ini bertujuan untuk memahami bagaimana isu-isu global menjadi perhatian oleh warga Indonesia sendiri dan digerakkan melalui teknologi Internet, yaitu petisi daring.

Adapun peneliti akan menggunakan dua konsep besar untuk memahami fenomena ini. Konsep pertama adalah mengenai petisi daring sebagai gerakan sosial digital. Secara prinsip, tujuan dari gerakan sosial ini sama, tetapi perbedaan dari penggunaan teknologi menghasilkan karakteristik yang sedikit berbeda. Konsep kedua adalah mengenai peran internet dalam globalisasi. Secara sederhana dapat dipahami bahwa Internet membuat informasi bergerak cepat melampaui batas-batas teritorial antarnegara.

\section{Petisi Daring sebagai Gerakan Sosial Digital}

Petisi bukanlah hal baru di Indonesia. Semenjak Republik Indonesia belum berdiri dan nusantara masih di bawah pemerintahan Hindia Belanda inisiatif pembuatan petisi telah dilakukan oleh segelintir rakyat. Ditilik dari konteks historis-politis saat itu memang arah dari petisi adalah untuk kegiatan politik. Jejak isu-isu politik dalam pembuatan petisi rupanya masih diikuti meskipun platform dan cara orang untuk berpartisipasi dalam petisi telah berubah.

Hal menarik yang dapat dilihat dari situs Change.org terkait hal ini adalah keberadaan isu populer yang diberi keterangan "sepanjang waktu" oleh pengelola situs. Dari gambar 1 ditemukan bahwa petisi yang menjadi objek kajian dalam penelitian ini adalah petisi yang paling populer dengan pendukung sebanyak 440.536 pendukung. Sementara di bawahnya ada dua isu lingkungan, yaitu tuntutan untuk menyelamatkan satwa Indonesia dan menghentikan sirkus keliling lumba-lumba. Serta ada satu isu bertema politik yaitu petisi penolakan UU MD3 yang berpotensi mematikan kritik. 


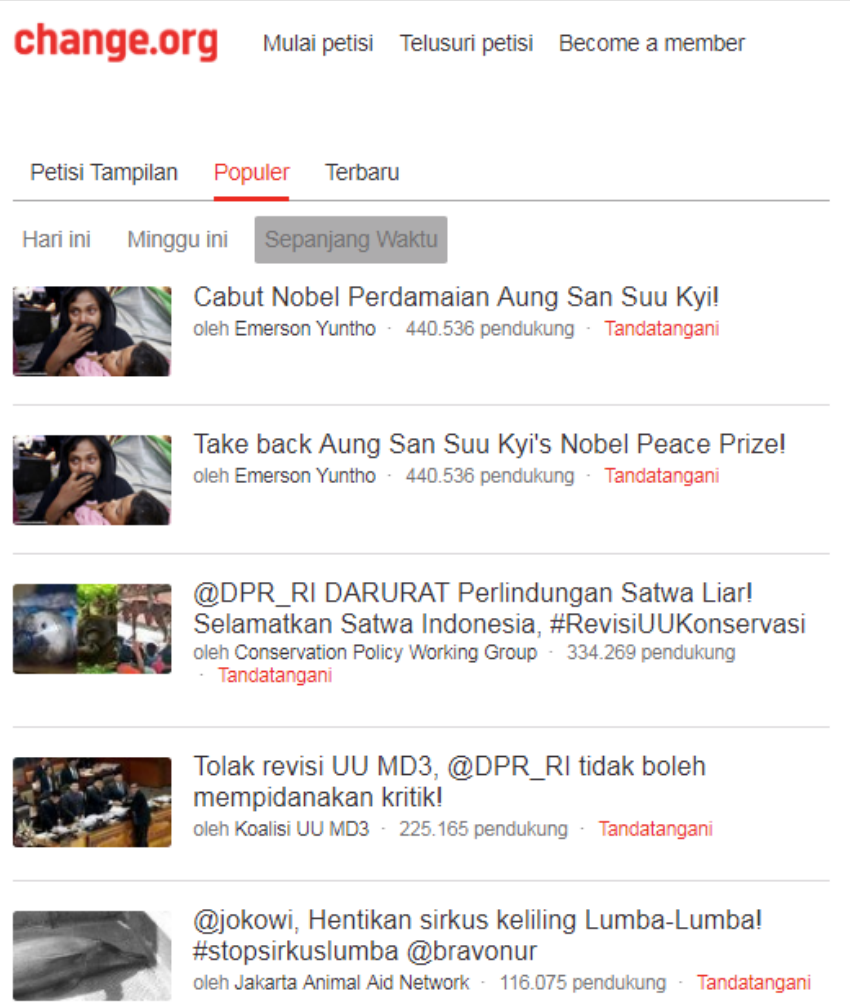

Gambar 1: Petisi Terpopuler di Change.org Indonesia (Sumber: Change.org)

Dengan menggunakan teknologi internet, berbagai strategi wacana dilakukan oleh pembuat petisi untuk mendapatkan dukungan kepedulian dari warganet. Sanjaya (2017) mengidentifikasi ada dua strategi wacana yang menguatkan peran sebuah petisi daring sebagai sebuah gerakan digital. Pertama, identitas pembuat petisi dan relevansinya dengan isu yang dia angkat. Kedua, urgensitas isu yang dijadikan topik petisi daring.

Penggunaan strategi wacana tersebut juga digunakan untuk menemukan kaitan antara petisi daring dengan gerakan sosial. Dalam rangka melihat kaitan gerakan sosial dengan penggunaan teknologi Internet, Laer \& Aelst (2010) membaginya menjadi dua dimensi yang saling terkait. Dasar pembagian dua dimensi adalah perlunya pembedaan antara aksi 'nyata' yang didukung dan difasilitasi oleh Internet dan aksi 'virtual' yang berbasis Internet. 


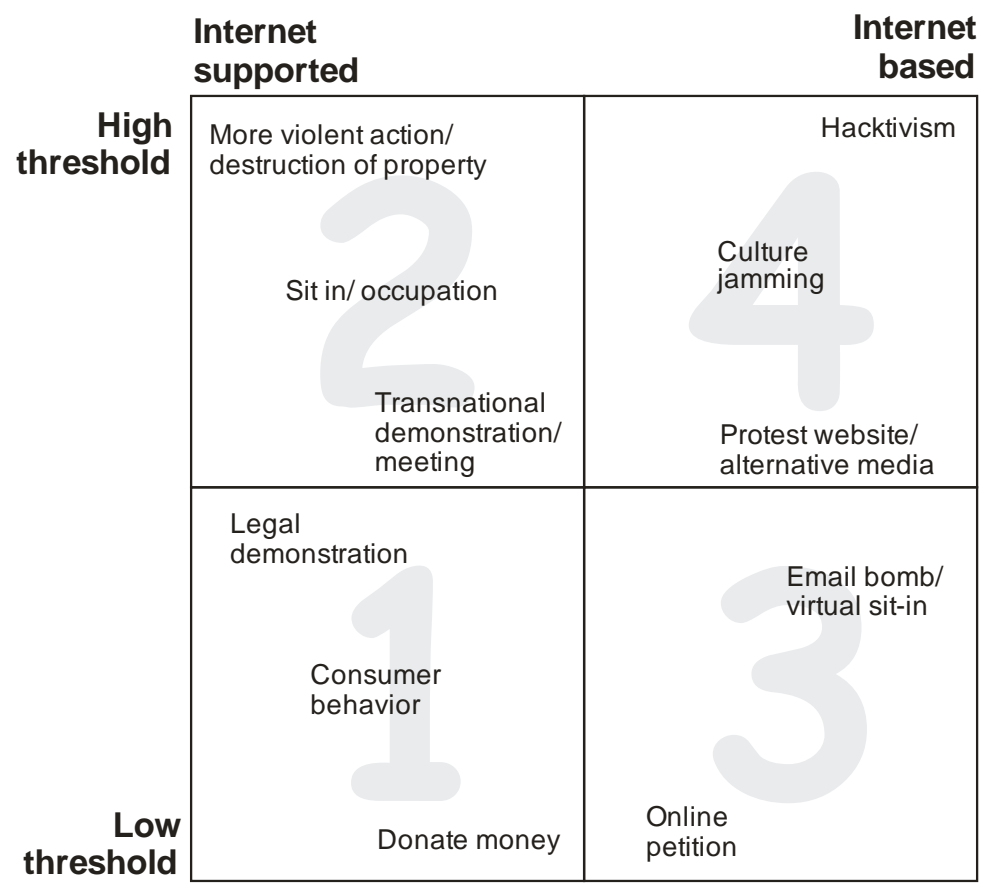

Gambar 2: Kuadran Hubungan Gerakan Sosial dengan Internet

(Sumber: Laer \& Aelst,2010)

Melalui kuadran di atas dapat diamati bahwa petisi daring berada pada kuadran ketiga. Kuadran ketiga ini terletak pada ambang batas yang rendah dan model "Internet based." Artinya, aksi yang dilakukan oleh para aktivis yang terlibat dalam petisi online ini cenderung tidak radikal bila dibandingkan dengan kuadran dua dan empat. Selain itu aksi tersebut memang benar-benar berdasarkan perkembangan teknologi internet, gerakan yang ada setelah teknologi tersebut ada. Maka, jelas terlihat bahwa internet menjadi salah satu hal utama dalam sebuah pergerakan sosial, bukan sebagai alat pendukung aksi.

Penandatanganan petisi online yang difasilitasi oleh Change.org dan situssitus serupa di Indonesia secara jelas menggambarkan kuadran tiga tersebut. Mereka menggunakan fasilitas ini bukan untuk menggalang bantuan dan mengumpulkan orang untuk aksi di jalan. Mereka benar-benar menggunakan internet sebagai basis pergerakan hingga tuntutan mereka dikabulkan oleh perorangan atau lembaga yang dipetisi.

\section{Peran Internet dalam Globalisasi}

Pada bagian ini dipaparkan beberapa pemikiran yang terkait dengan isu globalisasi pada tema-tema komunikasi dan media. Secara khusus, arah tulisan pada bagian ini membahas konsep globalisasi pada perusahaan multinasional berupa situs yang memfasilitasi warga untuk memberikan aspirasi dan tekanan berupa petisi daring. Maka, jenis media yang dibahas bukanlah media massa konvensional yang menyajikan berita dan informasi melalui proses jurnalisme, melainkan media yang digunakan oleh sekumpulan warga untuk melakukan protes demi pemenuhan kebutuhan publik. 
Secara garis besar globalisasi dapat didefinisikan sebagai meningkatnya keterhubungan global (Nash, 2010). Keterhubungan tersebut melibatkan arus barang, modal, orang, informasi, dan ide yang tersebar melampaui batas-batas geografis negara atau bahkan kebudayaan. Hal ini juga tentu didukung dengan adanya peluang-peluang yang muncul akibat berkembangnya jaringan perusahaan transnasional yang dilakukan dalam konteks internasional.

Sedangkan Gidden (1990), dalam Rantanen (2005), menyatakan globalisasi sebagai intensifikasi dari relasi sosial yang luas di seluruh dunia. Intensifikasi tersebut membuat suatu kejadian lokal dibentuk oleh perisitwa yang terjadi dari tempat yang jauh, dan sebaliknya. Melalui globalisasi itulah relasirelasi sosial, yang juga memungkinkan adanya inspirasi akan gerakan sosial, menjadi lebih mudah untuk dilakukan oleh warga negara di bagian manapun sesuai dengan konteks dan isu perjuangan mereka.

Dengan gagasan yang hampir sama, Albrow (1990), dalam Rantanen (2005), mendefinisikan globalisasi sebagai semua proses di mana orang-orang di dunia tergabung dalam masyarakat dunia yang satu atau yang disebut sebagai masyarakat global. Maka, globalisasi dapat didefinisikan sebagai proses di mana hal-hal yang berkaitan dengan ekonomi, politik, kultural, dan relasi sosial telah menjadi semakin dimediasi melampaui ruang dan waktu.

Globalisasi seringkali dikaitkan dengan jaringan sosial dan jaringan komunikasi. Ayuningtyas \& Abdullah (2017) menuliskan jaringan dapat terbentuk karena antara lain muncul rasa saling tahu dan saling menginformasikan dalam rangka melakukan sesuatu. Peran dari jaringan komunikasi tidak dapat diingkari menjadi salah satu hal utama dalam proses globalisasi. Nash (2010) menegaskan bahwa globalisasi ekonomi yang dikombinasikan dengan jaringan komunikasi digital merupakan kekuatan pendorong utama dari proses globalisasi, terutama pada pengembangan produk-produk baru, pelayanan, dan pasar.

Nash (2010) juga menyatakan bahwa penyebaran media global juga dapat membuat cara hidup yang sudah stabil menjadi kembali dipertanyakan karena dalam konteks isu tertentu teknologi digital membuat seluruh dunia menjadi dekat. Semua proses globalisasi dihubungkan dengan perkembangan terbaru dari teknologi informasi. Dalam konteks globalisasi ekonomi, pada umumnya globalisasi dikaitkan dengan kemampuan dalam memproses data dan teknlogi informasi yang mendukung sistem keuangan transnasional dan memfasilitasi pekerjaan dari korporasi multinasional.

Konteks transnasional ini dibahas juga oleh Morley \& Robins (1995) yang menyatakan organisasi dunia dan integrasi dari aktivitas perusahaan media membawa pada pemahaman mengenai ruang global dan lokal secara lebih dekat dan langsung. Hal-hal khusus yang hanya ditemui pada lingkup lokal dibawa pada logika jaringan transnasional. Hal ini dilakukan oleh kapitalis-kapitalis perusahaan media yang membuat ruang gambaran global (global image space) yang melampaui batas geografis, kehidupan sosial, dan pengetahuan yang tercakup dalam ruang-ruang budaya.

Apa yang dibentuk oleh Internet dan globalisasi saat ini adalah ruang budaya elektronik yang baru. Morley \& Robinson (1995) menjelaskannya sebagai simulasi dan gambaran geografis yang 'tidak bertempat' karena tidak spesifik 
menunjuk pada satu teritorial secara geografis. Formasi dari hyberspace global ini direfleksikan dalam pemikir-pemikir posmodernis. Kalangan tersebut menganggap bahwa arena global dari kultur adalah dunia di mana ada bentukbentuk komunikasi yang instan dan tidak mendalam. Artinya, sebuah dunia di mana batas-batas ruang dan waktu disingkatkan atau bahkan dirobohkan.

Globalisasi sangat mengubah pemahaman terhadap dunia (Morley \& Robins, 1995). Pemahaman itu berupa pengalaman tentang orientasi dan disorientasi, tentang pengertian identitas tempat maupun yang 'tanpa tempat'. Ikatan global-lokal seringkali diasosiasikan dengan relasi baru antara ruang dan tempat, kepastian dan pergerakan, pusat dan pinggiran, ruang nyata dan maya, dan konsep-konsep lain yang dulunya berseberangan

Masalahnya, kebanyakan ahli teori globalisasi cenderung mengaitkan kajian media dan komunikasi pada teori kultural dalam globalisasi. Hanya sebagian di antara mereka yang mengaitkan kedua hal itu dengan teori politik dan ekonomi dalam globalisasi (Rantanen, 2005). Maka, tulisan ini mencoba untuk mengaitkan tema partisipasi warga secara politis yang didorong oleh globalisasi dalam bidang komunikasi dan media.

Globalisasi yang didukung teknologi informasi yang baru kini sering dikaitkan dengan gerakan sosial secara global. Hal ini memberikan ruang bagi para aktivis gerakan untuk bisa berkoordinasi secara kolektif dengan melampaui batas-batas ruang dan waktu. Nash (2010) menegaskan bahwa bukan teknologi informasi yang menentukan perubahan sosial, tapi perubahan teknologi informasi ini memungkinkan orang untuk mengambil bagian melebihi batas-batas yang selama ini dibayangkan. Meskipun ketersediaan infrastruktur untuk aktivitas komunikasi ini tidak selalu mencukupi, teknologi informasi tetap dianggap sebagai kunci utama dari globalisasi. Hal ini terungkap dalam situs Change.org sebagai salah satu situs penyedia platform petisi daring yang akan dibahas lebih jauh pada bagian berikutnya.

\section{Metode Penelitian}

Penelitian ini berupaya memotret satu petisi daring di Indonesia yang menuntut pihak dari lembaga internasional untuk mengambil suatu tindakan yang penting untuk dilakukan. Petisi daring yang dipilih peneliti berasal dari situs Change.org, dengan judul "Cabut Nobel Perdamaian Aung San Suu Kyi" yang dibuat pada tahun 2016. Petisi ini dipilih karena menggambarkan tuntutan yang dibuat oleh orang di Indonesia, yaitu Emerson Yuntho. Pihak yang jadi sasaran adalah lembaga internasional: The Norwegian Nobel Committee 2016 beserta para anggota komitenya.

Komponen yang dianalisis dalam petisi daring tersebut adalah pada teks yang disusun oleh pembuat petisi. Teks tersebut bertujuan mengajak warganet untuk turut berpartisipasi dalam membagikan "tanda tangan"-yang dalam konteks ini adalah menyatakan memberi tanda tangan dengan mencentang menu yang telah disediakan. Hal yang termasuk dalam teks yang dimaksud adalah foto dan tulisan yang dibagi menjadi beberapa ragam. 
Teks tersebut dianalisis dengan menggunakan pendekatan analisis semiotika sosial yang pertama kali dimunculkan oleh M.A.K. Halliday (Santoso, 2008). Pendekatan ini merupakan turunan dari teori analisis wacana yang tidak hanya mengamati soal naskah sintagmatik, tetapi juga naskah paradigmatik.

Penelitian menggunakan semiotika sosial ini dilakukan dengan membedah teks menggunakan tiga komponen konteks situasi. Konteks situasi dalam hal ini dipandang sebagai keseluruhan lingkungan tempat teks beroperasi (Santoso, 2008). Adapun terdapat tiga hal dalam komponen tersebut, yaitu Medan Wacana (field of discourse), Pelibat Wacana (tenor of discourse), dan Sarana Wacana (mode of discourse). Komponen tersebut penting untuk dibahas dalam riset karena adanya penggunaan bahasa tertentu. Bahasa tidak lahir dari ruang kosong, maka pengamatan mengenai kondisi sosial dan kultural tempat teks diproduksi adalah hal yang penting (Halliday, 1978).

Pada bagian medan wacana peneliti bermaksud untuk menggaris bawahi ide utama atau isu besar yang menjadi dasar untuk pembuatan petisi daring yang dimaksud. Isu tersebut dikaitkan dengan kondisi sosial-politik, baik yang ada di dalam negeri maupun di luar negeri, yang turut memengaruhi pembentukan petisi tersebut. Kondisi tersebut ditunjukkan melalui data kronologis peristiwa-peristiwa yang saling berkaitan dengan tema serupa.

Pada bagian pelibat wacana peneliti berupaya untuk menelusuri secara daring latar belakang dan identitas dari pembuat wacana, yang dalam hal ini adalah Emerson Yuntho. Keterikatan dirinya pada suatu lembaga atau organisasi serta rekam jejak kerja yang tercantum dalam data di dunia digital akan digunakan untuk menjelaskan relevansi antara identitas pribadinya dengan isu yang dijadikan petisi. Beberapa nama tokoh besar yang dia cantumkan dalam narasi bersama dengan petisi tersebut juga ditelusuri secara proporsional.

Pada bagian sarana wacana peneliti akan memberi makna pada pilihanpilihan kata yang digunakan dalam narasi pengiring petisi tersebut. Santoso (2008) menerangkan beberapa hal yang perlu diperhatikan terkait sarana wacana ini adalah peran bahasa, tipe interaksi, medium saluran, serta modus retoris.

Ketiga unsur wacana tersebut berguna untuk membedah teks narasi dan memahami bagaimana penggunaan bahasa dalam narasi petisi online tersebut menunjukkan adanya gejala globalisasi yang terjadi dalam gerakan sosial digital di Indonesia. Peneliti melewati dua tahapan dalam rangka menjawab rumusan masalah dari penelitian ini. Pertama, identifikasi bahasa dan kata kunci yang digunakan. Kemudian, kedua, memaknai temuan pada langkah pertama dengan mengaitkannya pada konteks sosial dan politik di mana petisi tersebut muncul.

\section{Hasil Penemuan dan Diskusi}

Petisi dengan judul "Cabut Nobel Perdamaian Aung San Suu Kyi” dimulai pada tahun 2016 oleh Emerson Yuntho, koordinator Divisi Penggalangan Dana Publik Indonesia Corruption Watch (ICW). Yuntho mengajukan petisi tersebut kepada The Norwegian Nobel Committee 2016, secara khusus kepada enam orang anggota komite, yakni 1) Kaci Kullman Five; 2) Berit Reiss-Andersen; 3) IngerMarie Ytterhorn; 4) Henrik Syse; 5) Thorbjorn Jagland; dan 6) Olav Njolstad. 


\section{Analisis Medan Wacana}

Dalam rangka menemukan medan wacana dari teks yang dibaca, peneliti mengidentifikasi kalimat-kalimat dalam teks yang tersusun menjadi beberapa isu yang berurgensi tinggi. Isu pertama adalah mengenai pembunuhan besar-besaran atas suatu bangsa atau ras (genosida). Tertulis dalam teks: “..militer Myanmar di bawah pemerintahan Aung San Suu Kyi melakukan pembantaian besar-besaran kepada warga Rohingya..”

Mahkamah Pidana Internasional dalam dokumen Statuta Roma telah membahas empat jenis kejahatan internasional, yakni kejahatan genosida, kejahatan terhadap kemanusiaan, kejahatan perang, dan kejahatan agresi. Kecuali jenis kejahatan terakhir, tindakan pemerintah Myanmar diduga sudah memenuhi syarat untuk melakukan tiga jenis kejahatan internasional sekaligus.

Pasal 7 dalam dokumen tersebut menuliskan "pembunuhan" sebagai salah satu perbuatan kejahatan terhadap kemanusiaan. Sementara pasal 8 ayat 2a poin (1) menyebutkan "Pembunuhan yang dilakukan dengan sadar" sebagai pelanggaran berat terhadap Konvensi Jenewa tahun 1949. Dengan demikian pemerintah Myanmar juga telah melakukan kejahatan perang. Namun dalam laporan ini kejahatan yang dibahas difokuskan pada genosida saja lantaran menyangkut identitas agama yang dipeluk oleh warga Rohingya.

Genosida merupakan tragedi kemanusiaan yang tak luput dari perhatian para ilmuwan sosial di dunia internasional. Dalam buku "The Holocaust and Other Genocides: An Introduction" (2012) tercatat setidaknya ada lima tragedi genosida di dunia yang dipaparkan oleh para kontributor buku. Lima tragedi tersebut adalah: (1) The Holocaust, 1933-1941-1945; (2) The Armenian Genocide, 1915; (3) The Cambodian Genocide, 1975-1979; (4) The Rwandan Genocide, 1994; (5) Crisis and Genocide in Yugoslavia, 1985-1995.

Meskipun tidak tercatat sebagai aksi genosida yang pertama kali dalam sejarah dunia, Holocaust menjadi acuan standar (benchmark) bagi aksi-aksi genosida setelahnya karena pengaruhnya yang besar pada dunia. Holocaust adalah aksi pembantaian terhadap lebih dari enam juta bangsa Yahudi yang dilakukan oleh rezim Nazi yang mulai berkuasa di Jerman tahun 1933. Alasan pembantaian itu adalah untuk pemurnian "ras unggul" dalam tubuh bangsa Jerman. Bangsa Yahudi dianggap sebagai "ras inferior."

Situs United States Holocaust Memorial Museum juga melaporkan bahwa pemerintah Jerman saat itu juga menjadikan kelompok-kelompok lain sebagai sasaran karena dianggap memiliki "ras inferior" yaitu orang Roma (Gipsi), penyandang disabilitas, dan sebagian bangsa Slavia (Polandia, Rusia, dsb.). Sementara kaum Komunis, Sosialis, Kesaksian Yehova, serta kaum homoseksual juga dijadikan sasaran karena alasan politis, ideologis, dan perilaku.

Tragedi Holocaust ini mendorong organisasi internasional perserikatan bangsa-bangsa (PBB) untuk membentuk Genocide Convention atau Konvensi tentang Pencegahan dan Penghukuman Kejahatan Genosida pada bulan Desember 1948 (balitbangham.go.id). Pasal 2 dari konvensi tersebut menjelaskan genosida sebagai: 
“..setiap dari perbuatan, yang dilakukan dengan tujuan merusak begitu saja dalam keseluruhan ataupun sebagian, suatu kelompok bangsa, etnis, rasial atau agama seperti:

(a) Membunuh para anggota kelompok

(b) Menyebabkan luka-luka pada tubuh atau mental para anggota kelompok

(c) Dengan sengaja menimbulkan pada kelompok itu kondisi hidup yang menyebabkan kerusakan fisiknya dalam keseluruhan atau sebagian

(d) Mengenakan upaya-upaya yang dimaksudkan untuk mencegah kelahiran di dalam kelompok itu

(e) Dengan paksa mengalihkan anak-anak dari kelompok itu ke kelompok yang lain"

Berangkat dari konvensi ini dapat diduga pemerintah Myanmar di bawah kuasa Aung San Suu Kyi telah melakukan kejahatan terhadap kemanusiaan, kejahatan perang, dan terutama kejahatan genosida. Ketiga kejahatan tersebut disepakati sebagai kejahatan internasional. Maka dapat dipahami mengapa tragedi tersebut mendapat perhatian secara Internasional, termasuk dari Indonesia.

Isu kedua adalah mengenai korban yang adalah perempuan dan anak. Dalam teks tersebut ditemukan kalimat "Perempuan dan anak-anak juga merupakan korban dari pembantaian tersebut." Dalam kajian hukum humaniter isu perempuan dan anak-anak sebagai korban dari perang sudah banyak dibahas, meski korban masih saja berjatuhan. Seringkali perang memang bersifat maskulinistik dengan jargon-jargon seperti keberanian, kegagahan, keperkasaan, dan lain-lain (Gerungan, 2013).

Sumber yang sama menyebutkan bahwa pihak yang menerima dampak terbesar dari perang selama ini bukanlah kombatan (tentara), melainkan masyarakat yang sipil yang memiliki posisi lemah dan tidak bersenjata, yang sebagian besar di antaranya adalah perempuan dan anak-anak. Dari sudut pandang organisasi internasional, Majelis Umum PBB pada tahun 1974 telah mengeluarkan "The declaration on the protection of women and children in emergency" yang mengatur tentang perlindungan terhadap perempuan dan anakanak dalam keadaan darurat.

Dalam konteks riset ini, pembantaian yang dilakukan rezim Aung San Suu Kyi di Myanmar tentu bukanlah dilakukan dalam kondisi perang. Namun bagaimanapun pembantaian tersebut dilakukan oleh militer sebagai representasi negara, dan dilakukan dengan cara-cara yang sistematis sekaligus membabi buta terhadap warga negaranya sendiri. Maka kacamata yang paling tepat untuk mengkritik tindakan ini adalah Hak Asasi Manusia (HAM) dan genosida, yang merupakan kejahatan internasional.

Isu ketiga adalah mengenai agama Islam dan terorisme. Dalam teks tersebut ditemukan kutipan "...[bangsa Rohingya] mayoritas beragama Islam... upaya memberantas terorisme." Penulis mengusulkan dua latar belakang sosial-politik yang dapat menjelaskan isu tersebut, yaitu 1) terorisme dan citra Islam, dan 2) latar belakang sosio-religius masyarakat Indonesia. 
Citra Islam secara umum di dunia tak dapat dilepaskan dari peran media dan media sosial yang mengonstruksinya. Istilah yang tak dapat dilewatkan dari pembahasan mengenai Islam adalah "Islamophobia." Dalam riset mengenai Islamophobia di jejaring sosial Facebook, Awan (2016) mengidentifikasi beberapa label yang diberikan kepada penganut agama Islam atau Muslim. Label tersebut diantaranya: 1) Muslim dipandang sebagai teroris; 2) Muslim dipandang sebagai pemerkosa; 3) Perempuan Muslim dipandang sebagai ancaman karena pakaian yang mereka kenakan; dan 4) Muslim seharusnya dideportasi.

Alshammari (2013) dalam laporan risetnya menyebut Islamophobia sebagai "..acts of fear or hostility towards followers of Islamic religion." Akibat dari ketakutan tersebut adalah seringnya ditemui aksi diskriminatif yang dilakukan oleh orang-orang tertentu kepada pemeluk agama Islam. Dalam teks ini juga terdapat kutipan dari Aung San Suu Kyi yang bernada diskriminatif yaitu "Tak ada yang memberitahu bahwa saya akan diwawancarai oleh seorang muslim."

Sementara itu agama Islam adalah agama mayoritas warga Indonesia. Sebagai contoh, berdasarkan data Sensus Penduduk 2010 sebanyak 85,36 persen penduduk di DKI Jakarta beragama Islam (bps.go.id). Konsekuensinya adalah kehidupan sosial di Indonesia didominasi oleh kultur Islam. Maka dapat dipahami ketika Aung San Suu Kyi melakukan penindasan kepada bangsa Rohingya yang sebagian besar beragama Islam, muncul gerakan sosial dari Indonesia. Gerakan tersebut patut diduga sebagai bentuk solidaritas.

Isu keempat adalah mengenai nasib tidak jelas yang dialami pengungsi warga Rohingya. Dalam teks tersebut tertulis, "..kini banyak warga Rohingya yang mengungsi dan terdampar di perbatasan Bangladesh. Organisasi Migrasi Internasional (IOM) melaporkan sedikitnya 18.445 warga Rohingya yang mengungsi."

Persoalan pengungsi telah menjadi persoalan internasional. Pada tahun 1951 organisasi internasional UNHCR bahkan telah mengeluarkan dokumen berjudul "Konvensi dan Protokol mengenai Status Pengungsi." Dokumen ini salah satunya mengatur mengenai hak dan kewajiban pengungsi. Kewajiban pengungsi adalah mematuhi semua hukum dan peraturan atau ketentuan-ketentuan untuk menciptakan ketertiban umum di negara dimana dia ditempatkan.

Sementara itu hak-hak yang dimilik oleh pengungsi adalah sebagai berikut: Hak non diskriminasi; Hak status pribadi; Hak kesempatan atas hak milik; Hak berserikat; Hak berperkara di pengadilan; Hak atas pekerjaan yang menghasilkan; Hak atas pendidikan dan pengajaran; Hak kebebasan bergerak; Hak atas kesejahteraan sosial; Hak atas tanda pengenal dan dokumen perjalanan; Hak untuk tidak diusir

Lantas bagaimana nasib pengungsi Rohingya di Bangladesh seperti yang dituliskan? Sky Wheeler, seorang peneliti di Human Right Watch (HRW), melaporkan hanya sebagian kecil pengungsi korban pemerkosaan yang mendapatkan perawatan (hrw.org). Salah satu alasan kelambanan perawatan itu adalah persoalan dana. Untuk informasi, berdasar penelusuran laporan yang diterbitkan media daring menyebutkan gelombang pengungsi belum berakhir. Tanggal 20 April 2018 kemarin bahkan dilaporkan nelayan di Aceh kembali 
menyelamatkan pengungsi Rohingya sebanyak 79 orang (bbc.com). Sambil menunggu informasi dari IOM, pemerintah sementara menampung pengungsi ini pada tempat yang disediakan.

\section{Pelibat Wacana}

Penting bagi publik untuk mengetahui latar belakang dari orang-orang yang membuat dan mendukung petisi tersebut. Relevansi yang ditemukan antara latar belakang dari pembuat petisi dengan isi petisi tentu memiliki pengaruh di kognisi pembaca. Peneliti membatasi penelusuran secara daring kepada Emerson Yuntho sebagai pembuat petisi. Selain itu juga penelusuran proporsional kepada empat nama teratas setelah pembuat petisi, yakni Tsamara Amany, Hamid Basyaib, Agus Sari, dan Nong Darol Mahmada.

Ketika membuat petisi ini Emerson Yuntho berstatus sebagai Koordinator Divisi Monitoring dan Peradilan Indonesia Corruption Watch (ICW). Dalam situs resmi organisasi (antikorupsi.org) ICW memiliki visi "Menguatnya posisi tawar rakyat untuk mengontrol negara dan turut serta dalam keputusan untuk mewujudkan tata kelola pemerintahan yang demokratis, bebas dari korupsi, berkeadilan ekonomi, sosial, serta jender." Barangkali terlalu jauh untuk mengaitkan petisi ini dengan visi ICW, tetapi pandangan aktivisme dan gerakan sosial yang dimiliki Emerson Yutho dapat diduga sejalan dengan visi lembaga ini.

Adapun penjelasan latar belakang Emerson Yuntho empat nama teratas yang diturutsertakan dalam petisi ini dapat dilihat pada tabel berikut.

Tabel 1. Pembuat dan Pendukung Petisi

\begin{tabular}{ccl}
\hline No. & \multicolumn{1}{c}{ Tokoh } & \multicolumn{1}{c}{ Latar Belakang } \\
\hline 1 & Emerson Yuntho & $\begin{array}{l}\text { Koordinator Divisi Monitoring dan Peradilan } \\
\text { Indonesia Corruption Watch (ICW) }\end{array}$ \\
2 & Tsamara Amany & $\begin{array}{l}\text { Ketua DPP Partai Solidaritas Indonesia (PSI) } \\
\text { Komisaris Utama PT Balai Pustaka (Persero), } \\
\text { aktivis }\end{array}$ \\
3 & Hamid Basyaib & $\begin{array}{l}\text { Aktivis lingkungan, pengajar di ITB, CEO PT } \\
\text { Bentang Alam Indonesia; Senior Associate }\end{array}$ \\
4 & Agus Sari & $\begin{array}{l}\text { ICRAF } \\
\text { Deputy Director di Freedom Institute, salah satu } \\
\text { pendiri Jaringan Islam Liberal (JIL) }\end{array}$ \\
& &
\end{tabular}

Sumber: dari berbagai sumber

Ditilik dari latar belakang identitas pendukung petisi ini dapat disimpulkan bahwa mereka berasal dari beragam sektor. Sektor politik digawangi oleh Tsamany Amary, sektor aktivis diwakili oleh Hamid Basyaib dan Agus Sari, sementara dari organisasi agama diwakili Nong Darol Mahmada. Hal ini menunjukkan beberapa hal penting, di antaranya 1) persoalan Rohingya adalah persoalan kemanusiaan secara universal; 2) kuasa politik dan aktivisme dibutuhkan untuk menguatkan gema gerakan sosial; dan 3) identitas Islam digunakan sebagai alat pencari dukungan. 


\section{Analisis Sarana Wacana}

Pada bagian ini penulis memaparkan analisis mengenai penggunaan bahasa yang tampak dalam teks. Penggunaan bahasa penting untuk dianalisis sebab bahasa mengantarkan pembaca pada realitas yang dikonstruksi oleh produsen teks. Terdapat tiga bagian yang dibahas, yakni diksi provokatif, deskripsi sosok Aung San Suu Kyi, dan penggunaan majas ironi.

Pembuat petisi tampaknya memahami bahwa pilihan kata (diksi) yang berbeda akan menciptakan kesan yang berbeda pula pada benak pembaca. Dalam teks dituliskan kata "pembunuhan" dan "pembantaian" secara bergantian. Penjelasan tersebut secara jelas ditampilkan dalam tabel berikut.

Tabel 2. Arti Kata Menurut KBBI Daring

\begin{tabular}{ll}
\hline \multicolumn{1}{c}{ Kata } & \multicolumn{1}{c}{ Arti } \\
\hline Bunuh & $v$ habisi nyawa secara sengaja \\
Pembunuhan & $n$ proses, cara, perbuatan membunuh \\
Bantai & $n$ daging (binatang yang disembelih) \\
& $n$ proses, cara, perbuatan membantai; \\
& penyembelihan; pemotongan \\
& $n$ tempat menyembelih (sapi, kerbau, dan \\
Pembantaian & sebagainya); pejagalan \\
& $n$ ki pembunuhan secara kejam dengan \\
& korban lebih dari seorang \\
\hline \multicolumn{1}{c}{ Sumber: KBBI Daring (kbbi.kemdikbud.go.id) }
\end{tabular}

Maka penggunaan kata "pembantaian" dalam teks tersebut dapat dimaknai dengan dua cara. Pertama, merujuk pada pengertian ketiga dari "pembantaian", kata ini lebih menerangkan cara atau modus dan dampak. Istilah tersebut lebih provokatif dan lebih mampu mendeskripsikan apa yang terjadi di Myanmbar dibandingkan dengan istilah "pembunuhan" saja.

Makna kedua adalah mengenai kemanusiaan. Merujuk pada arti "bantai" dan arti kedua dan ketiga dari "pembantaian" penulis tampak hendak mengatakan bahwa tindakan pemerintah Myanmar ini sudah tidak lagi memandang sisi kemanusiaan warga Rohingya. Dengan kata lain, pemerintah Myanmar melihat warga Rohingya memiliki kedudukan setara dengan binatang sehingga layak untuk diberi kata "bantai."

Adapun pengusul petisi ini juga menggunakan cara mendeskripsikan sosok Aung San Suu Kyi dalam teks yang diproduksi. Sosok tersebut dilekatkan dengan sifat "penyabar" dan memiliki sikap "berjuang dalam damai" dalam rangka meraih kekuasaan di Myanmar. Selain itu, hal yang lebih penting adalah kalimat yang menyatakan bahwa banyak orang di berbagai negara yang "kagum terhadap sosok Suu Kyi” karena deskripsi tadi.

Sifat, sikap, dan kekaguman terhadap Suu Kyi tadi lantas dihadapkan pada kenyataan bahwa "banyak orang kecewa dan marah" karena dia mempermasalahkan seorang jurnalis Muslim. Dari teks tersebut tampak bahwa penulis mengarahkan pembaca pada hal kontras yang ada dalam diri Suu Kyi. 
Kekontrasan itulah yang lalu dilegitimasi melalui kata "banyak orang" untuk mengatakan bahwa tuntutan ini mewakili orang-orang lain di luar sana.

Sementara itu, cara ketiga yang digunakan oleh pembuat petisi adalah menggunakan majas ironi. Berikut kutipan dalam teks:

"Sebagai peraih perdamaian pernyataan rasis atau pembiaran terhadap kekerasan atau pembantantaian entnis Rohingya justru membuat perdamaian menjadi semu, memunculkan sikap saling curiga bahkan konflik..... Hanya mereka yang sungguh-sungguh menjaga kedamaian yang layak menerima hadiah Nobel Perdamaian."

Kalimat tersebut bernada ironi karena peraih penghargaan Nobel Perdamaian ternyata justru pihak yang melakukan pembiaran pembantaian terhadap etnis Rohingya di wilayahnya. Suu Kyi tidak dipandang sebagai orang yang netral dalam aksi kekerasan tersebut karena dia memiliki kuasa untuk mencegah.

\section{Simpulan}

Petisi adalah tuntutan kolektif. Petisi muncul dari kesadaran sekelompok orang akan sesuatu yang salah dan perlu diubah. Mereka menuntut pihak yang punya kuasa untuk melakukan suatu tindakan khusus melalui kuasanya. Maka kredibilitas dan citra dari pihak yang dituntut sedang dipertaruhkan dalam petisi ini. Penelitian ini membongkar praktik produksi teks pada pengantar petisi. Teks pengantar tersebut diperlukan guna menjelaskan konteks tuntutan yang diperjuangkan. Konteks globalisasi dalam petisi ini menunjukkan bahwa teknologi internet memang betul menembus batas-batas budaya, ruang, dan waktu. Maka memang dibutuhkan strategi-strategi tertentu untuk membuat petisi ini mendapat banyak dukungan dari warga.

Berdasar analisis medan wacana ditemukan empat isu utama yaitu genosida, korban perempuan dan anak, citra Islam di dunia internasional, serta kasus pengungsi. Isu utama tersebut adalah persoalan internasional yang mendorong PBB untuk membentuk perjanjian-perjanjian khusus dalam hukum internasional. Pemilihan isu tersebut tepat mengingat petisi atas kejadian di Rohingya ini dibuat di Indonesia.

Pada bagian pelibat wacana ditemukan fakta bahwa orang-orang yang berada di balik petisi ini adalah aktivis yang bergerak pada isu warga, HAM, serta politik. Hal ini menunjukkan keberagaman sekaligus urgensi dimunculkan petisi ini. Diplomasi internasional tentu menjadi ujung tombak dari resolusi dan penegakan hukum atas kejahatan internasional di Myanmar. Namun petisi ini berguna untuk meresonansi isu, menggugah kesadaran kolektif bangsa lain akan kondisi di Myanmar.

Sementara itu penggunaan bahasa tertentu digunakan untuk mencapai manfaat yang terakhir tersebut. Strategi ini dilakukan melalui penggunaan istilah "bantai" yang bernada anti-kemanusiaan, deskripsi sosok Aung San Suu Kyi yang mengecewakan, hingga penggunaan majas ironi. 
Maka penelitian ini menunjukkan sebuah potret globalisasi dalam gerakan sosial digital di Indonesia. Mereka mengajak warga untuk turut peduli pada isuisu internasional. Salah satu cara untuk membuat persoalan itu relevan dengan warga Indonesia adalah dengan mengaitkan isu agama.

Penelitian ini menggugah peluang untuk melakukan penelitian lebih lanjut mengenai tema ini. Peluang penting tersebut adalah memahami fenomena ini sebagai alat diplomasi politik melalui teknologi digital. Diplomasi adalah ujung tombak dari perjuangan-perjuangan yang salah satunya dibahas dalam penelitian ini.

\section{Ucapan Terima Kasih}

Penelitian ini dilakukan secara mandiri. Bagaimanapun, prosesnya tidak dapat selesai dilakukan tanpa ekosistem akademis yang memadahi di sekitar peneliti. Maka perlu peneliti ucapkan terima kasih kepada segenap staf akademik di Program Studi Ilmu Komunikasi dan Program Studi Ilmu Hukum di Fakultas Hukum dan Komunikasi Universitas Katolik Soegijapranata atas referensi dan dukungan moral yang diberikan. Peneliti juga mengucapkan terima kasih kepada segenap pengurus Jurnal Komunikasi Universitas Tarumanagara yang telah memberi kesempatan untuk memuat artikel ini.

\section{Daftar Pustaka}

Alshammari, Dalal. (2013). Islamophobia. International Journal of Humanities and Social Science Vol. 3 No. 15. 177-180

Awan, Imran. (2016). Islamophobia on Social Media: A Qualitative Analysis of the Facebook's Walls of Hate. International Journal of Cyber Criminology Vol 10 Issue 1. 1-20

Ayuningtyas F. \& Abdullah, A. Z. (2017). Kognisi Sosial Melalui Situs Jejaring Youtube Pada Komunitas Online (Studi Kasus pada Komunitas Online LinkPictureID). Jurnal Komunikasi, Vol 9 No. 2, 137-150. Terarsip di: https://journal.untar.ac.id/index.php/komunikasi/article/view/1076/831

BBC.com. (2018). Lagi, Nelayan Aceh Selamatkan 79 Pengungsi Rohingya. Diakses pada tautan http://www.bbc.com/indonesia/indonesia-43837197 23 Mei 2018.

Boender, Barbara \& Have, Wichert ten (eds.). (2012). The Holocaust and Other Genocides: An Introduction. Amsterdam: Amsterdam University Press.

BPS Sensus Penduduk 2010. Penduduk Menurut Kelompok Umur dan Agama yang Dianut di Provinsi DKI Jakarta. Diunduh dari https://sp2010.bps.go.id/index.php/site/tabel?searchtabel=Penduduk+Menurut+Kelompok+Umur+dan+Agama+yang+Dianut\&t id=320\&searchwilayah=Provinsi + DKI+Jakarta\&wid=3100000000\&lang=id (akses 23 Mei 2018)

Change.org. (n.d.). Retrieved April 12, 2015, from www.change.org: https://www.change.org/id/tentang 
Donk, W. v., Loader, B. D., Nixon, P. G., \& Rucht, D. (2004). Social Movements and ICTs. In W. v. Donk, B. D. Loader, P. G. Nixon, \& D. (. Rucht, Cyberprotest: New Media, Citizens, and Social Movements (pp. 1-22). London: Routledge.

Fishkin, J. S. (2009). When the People Speak: Deliberative Democracy and Public Consultation. New York: Oxford University Press.

Garrett, R. K. (2006). Protest in an Information Society: A Review of Literature on Social Movements and New ICTs. Information, Communication, and Society, 9(2), 202-224.

Gerungan, Lusy K.F.R. (2013). Perlindungan Terhadap Perempuan Dan Anak Ketika Perang Dalam Hukum Huminiter Internasional. Jurnal Hukum Unsrat Vol 21, No 3. 76-85

Konvensi tentang Pencegahan dan Penghukuman Kejahatan Genosida. Diunduh dari http://www.balitbangham.go.id/pocontent/peraturan/Konvensi\%20Kejahatan\%20Genosida.pdf (akses 22 Mei 2018)

Laer, J. V., \& Aelst, P. V. (2010). Cyber-Protest and Civil Society: the Internet and Action Repertoires in Social Movements. In Y. Jewkes, \& M. Y. (eds.), Handbook on Internet Crime (pp. 230-254). Milton: Willan Publishing.

Morley, D., \& Robins, K. (1995). Spaces of Identity: Global Media, Electronic Landscapes and Cultural Boundaries. London: Routledge.

Nash, K. (2010). Contemporary Political Sociology: Globalization, Politics, and Power. Hoboken: Blackwell Publishers.

Rantanen, T. (2005). The Media and Globalization. London: Sage Publication Ltd.

Romero, L. D. (2014). On the Web and Contemporary Social Movements. In B. Patrut, \& M. P. (eds.), Social Media in Politics: Case Studies on the Political Power of Social Media (pp. 19-34). Bacau: Springer.

Sanjaya, A. R. (2017). Wacana Lingkungan dalam Gerakan Sosial Digital. Jurnal IPTEK-KOM Vol. 19 No. 2. 133-148.

Santoso, A. 2008. Jejak Halliday dalam Linguistik Kritis dan Analisis Wacana Kritis. Jurnal Bahasa dan Seni. Vol. 36(1). 1-14.

Schesser, S. D. (2006). A New Domain for Public Speech: Opening Public Spaces Online. California Law Review, Vol. 94, No. 6 , 1791-1825.

UNHCR. (1951). Konvensi dan Protokol Mengenai Status Pengungsi. Diunduh dari

http://www.unhcr.org/id/wpcontent/uploads/sites/42/2017/05/KonfensidanProtokol.pdf (akses 23 Mei 2018)

United States Holocaust Memorial Museum. Holocaust. Diunduh dari https://www.ushmm.org/wlc/id/article.php?ModuleId=10005143 (akses 22 Mei 2018)

Wheeler, Skye. (2018). Orang Rohingya Korban Pemerkosaan Diabaikan di Bangladesh. Diakses pada situs Human Rights Watch https://www.hrw.org/id/news/2018/02/23/315682 pada 23 Mei 2018 